\title{
Spectrophotometric Determination of Microgram Amounts of Aliphatic Amines with Quinalizarin
}

\author{
T. S. Al-Ghabsha A. M. S. Al-Delymi \\ Department of Chemistry / College of Education \\ Mosul University
}

Received
$09 / 10 / 2007$

Accepted

$09 / 10 / 2007 \quad 03 / 12 / 2007$

\begin{abstract}
الخلاصة
تم نطوير طريقة طيفية بسيطة وسريعة وحساسة لتقدير الأمينات الاليفاتية، تعتمد الطريقة

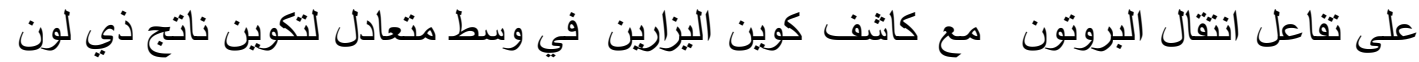

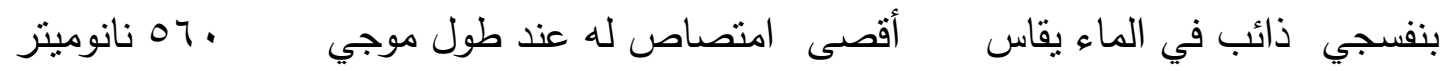

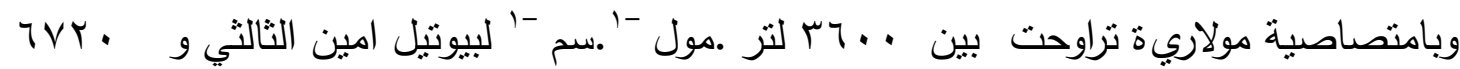

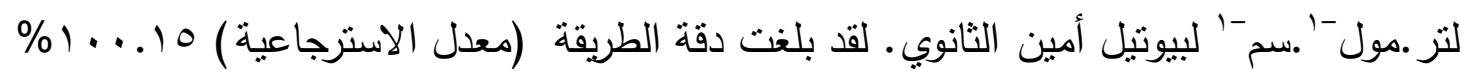

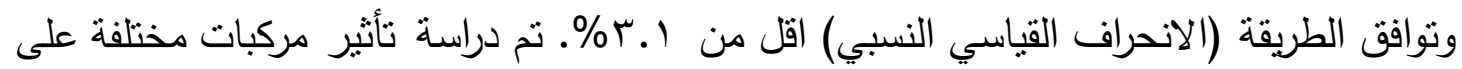
تقدير الأمينات الاليفاينة كما تم إيجاد طبيعة وثابت استقرار النواتج المتكونة.
\end{abstract}

\section{ABSTRACT}

A simple, rapid and sensitive spectrophotometric method for the determination of aliphatic amines was developed. The method is based on the proton transfer reaction with quinalizarin reagent in aqueous neutral solution to form violet product which shows maximum absorbance at 560 $\mathrm{nm}$ with molar absorptivity ranged between $36001 . \mathrm{mol}^{-1} . \mathrm{cm}^{-1}$ for terbutyl amine to $67201 . \mathrm{mol}^{-1} \cdot \mathrm{cm}^{-1}$ for sec-butyl amine. The accuracy (average recovery) of the method was $100.15 \%$ and the precision (RSD) was less than $3.1 \%$. The effect of various compounds on the determination of aliphatic amines has been studied. The nature and stability constant of the products have been estimated.

\section{INTRODUCTION}

Amines are organic derivatives of ammonia, containing a nitrogen atom with a lone pair of electrons, making amines basic and nucleophilic therefore most of the chemistry of amines depends on the presence of this lone pair of electrons ${ }^{(1,2)}$. Aliphatic amines find application in numerous and varied industries, including chemicals, paper, rubber, corrosion, 
plastic and textile. Ethylamine may play important role in initiating the gastrin secretory response to a meal. Cyclohexylamine is a reactive primary amine, serving as an intermediate for a variety of useful amine derivatives $^{(3,4)}$.

Various $\pi$ acceptors have been used for the determination of amines spectrophotometrically via $\mathrm{n}-\pi$ CT-complex formation reaction with 2,4,7-trinitrofluorenone ${ }^{(5)}$, p-benzoquinone ${ }^{(6)}, \quad 2,6$-dichloro-pbenzoquinone $^{(7)}$, trinitrobenzene ${ }^{(8)}$, 2,3,5,6-tetrachloro-p-benzoquinone (Chloranil) $^{(9-12)}$, 2,3,5,6-tetrafluoro-p-benzoquinone (Fluoranil) ${ }^{(13)}, 2,3$ dichloro-5,6-dicyano-p-benzoquinone (DDQ) ${ }^{(14,15)}$ and 2,3,5,6tetrabromo-p-benzoquinone (Bromanil) ${ }^{(16)}$.

Benzylamine was determined spectrophotomertically by its reaction with $\mathrm{Cu}-\mathrm{NTA}$ complex in aqueous solution leading to increase the absorbance at $\lambda_{\max } 832 \mathrm{~nm}$ with accuracy of $99 \%$ and RSD $<4.6 \%{ }^{(17)}$.

Primary and secondary aliphatic amines were determined spectrophotometrically by their reaction with 1,2,5,8-tetrahydroxy 9,10 anthraquinone (quinalizarin) forming violet adduct in aqueous solution $^{(18,19)}$. Spectrophotometric method used for the determination of ethylamine using tetracyanoethylene (TCNE) reagent at $\lambda_{\max } 325 \mathrm{~nm}$ in aqueous solution with a molar absorptivity of $28311 \cdot \mathrm{mol}^{-1} \cdot \mathrm{cm}^{-1}(20) \cdot 2,4-$ Dinitro-1-fluorobenzene (DNFB) used for the spectrophotometric determination of cyclohexylamine at $\lambda_{\max } 353 \mathrm{~nm}$ in the organic medium with molar absorptivity of $13957 \mathrm{l} \cdot \mathrm{mol}^{-1} \cdot \mathrm{cm}^{-1}(21)$.

Recently spectrophotometric method used for the determination of microgram amounts of aliphatic amines based on the proton transfer reaction using 3,5-dinitrosalicylic acid (DNS) reagent in basic medium forming coloured products with maximum absorption at $415 \mathrm{~nm}$. The molar absorptivity ranged from $51001 . \mathrm{mol}^{-1} . \mathrm{cm}^{-1}$ for tributylamine to $120001 . \mathrm{mol}^{-1} . \mathrm{cm}^{-1}$ for dibutylamine ${ }^{(22)}$.

In this work quinalizarin reagent was used for the spectrophotometric determination of aliphatic amines via proton transfer reaction in aqueous solution.

\section{Apparatus}

\section{EXPERIMENTAL}

A Shimadzu UV-210 A digital double beam spectrophotometer with $1-\mathrm{cm}$ matched quartz cells was used for all spectral and absorbance measurements.

\section{Reagents}

All chemicals used were of the highest purity available. Quinalizarin $\left(2 \times 10^{-4} \mathrm{M}\right)$ solution:

This solution was prepared by dissolving $0.0136 \mathrm{~g}$ of quinalizarin in absolute ethanol in $250 \mathrm{ml}$ volumetric flask. This solution was kept in brown bottle and it was stable for at least one month. 


\section{Aliphatic amines standard solutions}

Ethylamine, sec-butylamine, tert-butylamine, benzylamine, dibenzylamine and cyclohexylamine were used in this work. Each compound of $100 \mathrm{ppm}$ was prepared in aqueous solution.

\section{Procedure for calibration}

To a series of $10 \mathrm{ml}$ calibrated flasks, transfer increasing volumes (mls) of $100 \mathrm{ppm}$ of each amine solution to cover the concentration ranges as cited in (Table 3), followed by addition of optimum amounts of quinalizarin solution (Table 2). The solutions were then diluted to the mark with distilled water. Under the optimum conditions mentioned in Table (2), the absorbances were measured at $560 \mathrm{~nm}$ against reagent blank.

\section{RESULTS AND DISCUSSION}

\section{Preliminary investigation}

When dilute aqueous solution of ethylamine as a typical aliphatic amine and quinalizarin reagent were mixed in a aqueous solution a violet solution was observed with maximum absorption at $560 \mathrm{~nm}$ in contrast to the reagent blank which shows a maximum absorption at $490 \mathrm{~nm}$ (Fig. 1).

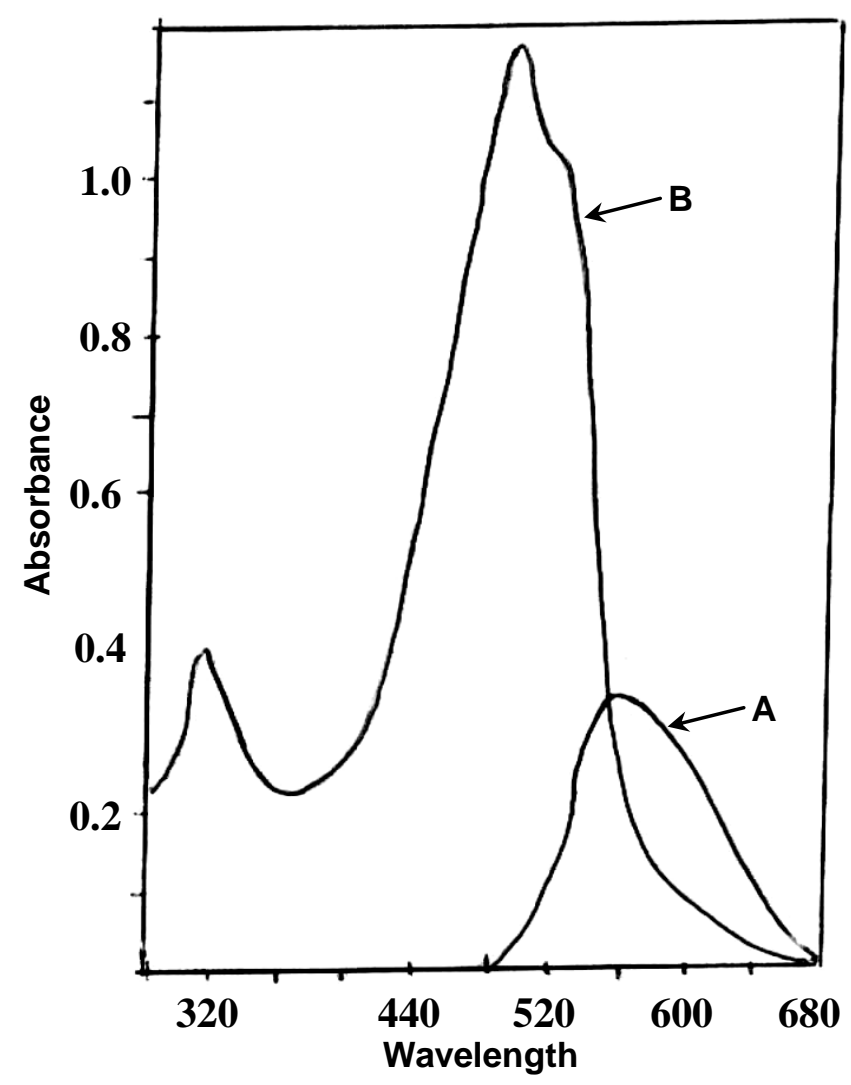

Figure (1): Absorption spectra of:

A: Ethylamine-Quinalizarin product versus reagent blank

$B$ : Reagent blank versus distilled water 


\section{Optimization of conditions}

The $\mathrm{pH}$ of ethylamine, a typical aliphatic amine was examined, it was 8 . After the addition of $6 \mathrm{ml}$ of $2 \times 10^{-4} \mathrm{M}$ quinalizarin the value of $\mathrm{pH}$ decreased to 7.2 therefore different buffers of $\mathrm{pH} 7.2$ were prepared such as borate, carbonate, acetate and phosphate. It was found that these buffers decrease the absorbance (Table 1).

Table (1): Effect of buffer on the absorption of product

\begin{tabular}{|c|c|c|c|c|c|}
\hline $\begin{array}{c}\text { Buffer solutions } \\
(\mathrm{pH} 7.2)\end{array}$ & Borate & Carbonate & Acetate & Phosphate & Without \\
\hline Absorbance & 0.045 & 0.027 & 0.076 & 0.068 & 0.418 \\
\hline
\end{tabular}

The effect of various parameters on the absorption of the coloured product has been investigated and the reaction conditions were optimized for each aliphatic amine. Table (2) shows summary of the optimum conditions for the determination of the studied aliphatic amines.

Table (2): Summary of optimum conditions for the determination of aliphatic amines

\begin{tabular}{|c|c|c|c|c|c|}
\hline Aliphatic amines & $\lambda_{\max }(\mathrm{nm})$ & $\begin{array}{c}\text { Temp. } \\
\left({ }^{\circ} \mathrm{C}\right)\end{array}$ & $\begin{array}{c}\text { Development } \\
\text { time }(\mathrm{min})\end{array}$ & $\begin{array}{c}\text { Stability } \\
\text { period } \\
(\mathrm{min})\end{array}$ & $\begin{array}{c}\text { Quinalizarin } \\
2 \times 10^{-4} \mathrm{M} \\
(\mathrm{ml})\end{array}$ \\
\hline Ethylamine & 560 & 50 & 35 & 25 & 6 \\
\hline sec-Butylamine & 560 & 40 & 50 & 40 & 6.5 \\
\hline tert-Butylamine & 560 & 40 & 30 & 15 & 6.0 \\
\hline Benzylamine & 560 & 40 & 30 & 30 & 5 \\
\hline Dibenzylamine & 560 & RT & 20 & 25 & 5 \\
\hline Cyclohexylamine & 560 & RT & 10 & 50 & 6 \\
\hline
\end{tabular}

\section{Analytical data}

Under these optimum conditions, linear correlation were obtained for the aliphatic amines over the ranges shown in Table (3). A negative deviation from Beer's law was observed at higher concentrations of aliphatic amines. The molar absorptivities for aliphatic amines ranged between $36001 . \mathrm{mol}^{-1} . \mathrm{cm}^{-1}$ for tert-butylamine and $67201 . \mathrm{mol}^{-1} . \mathrm{cm}^{-1}$ for sec-butylamine indicates the method is sensitive. 

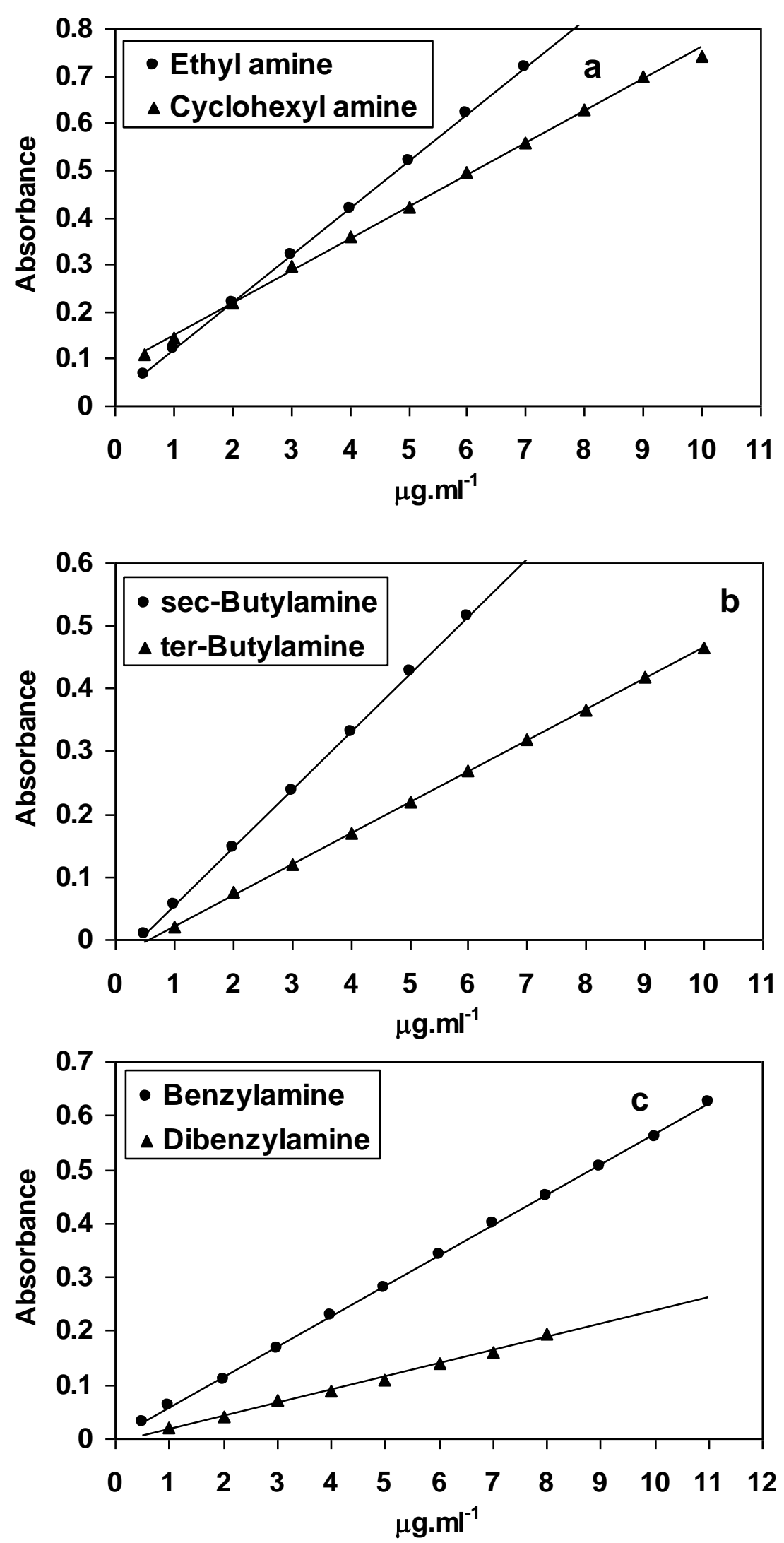

Figure (2): Calibration graphs of:

a: Ethylamine and cyclohexylamine

b: sec-Butylamine and tert-butylamine

c: Benzylamine and dibenzylamine 
Table (3): Analytical parameters

\begin{tabular}{|c|c|c|c|c|c|}
\hline Aliphatic amines & $\begin{array}{c}\text { Linearity } \\
\text { range } \\
\left(\mu \mathrm{g} \cdot \mathrm{ml}^{-1}\right)\end{array}$ & $\begin{array}{c}\text { Molar } \\
\text { absorptivity } \\
\left(\mathrm{l.mol}^{-1} . \mathrm{cm}^{-1}\right)\end{array}$ & Slope & Intercept & $\begin{array}{c}\text { Correlation } \\
\text { coefficient }\end{array}$ \\
\hline Ethylamine & $0.5-7$ & 4490 & 0.0999 & 0.0192 & 1.0000 \\
\hline sec-Butylamine & $0.5-6$ & 6720 & 0.0921 & -0.037 & 0.9999 \\
\hline tert-Butylamine & $1-10$ & 3600 & 0.0493 & -0.0256 & 0.9998 \\
\hline Benzylamine & $0.5-11$ & 6030 & 0.0563 & 0.0015 & 0.9998 \\
\hline Dibenzylamine & $1-8$ & 4830 & 0.0245 & -0.0067 & 0.996 \\
\hline Cyclohexylamine & $0.5-10$ & 6690 & 0.0676 & 0.0832 & 0.9985 \\
\hline
\end{tabular}

\section{Accuracy and precision}

The recovery and the relative standard deviation (RSD) were determined at three different concentrations. The results shown in Table (4) indicate very good accuracy (average recovery \%) $100.15 \%$ while the $\mathrm{RSD}$ is $<3.1 \%$.

Table (4): The accuracy and precision of the method

\begin{tabular}{|c|c|c|c|c|}
\hline Aliphatic amines & $\begin{array}{c}\text { Amount added } \\
\left(\mu \mathrm{g} \cdot \mathrm{ml}^{-1}\right)\end{array}$ & $\begin{array}{c}\text { Recovery* } \\
(\%)\end{array}$ & $\begin{array}{c}\text { Average } \\
\text { recovery }(\%)\end{array}$ & $\mathrm{RSD}^{*}(\%)$ \\
\hline \multirow{3}{*}{ Ethylamine } & 2 & 98.17 & \multirow{3}{*}{99.49} & 1.75 \\
\hline & 4 & 100.96 & & 0.87 \\
\hline & 6 & 99.35 & & 0.55 \\
\hline \multirow{3}{*}{ sec-Butylamine } & 3 & 97.90 & \multirow{3}{*}{99.31} & 1.30 \\
\hline & 4 & 101.21 & & 0.91 \\
\hline & 5 & 98.83 & & 0.77 \\
\hline \multirow{3}{*}{ tert-Butylamine } & 4 & 102.34 & \multirow{3}{*}{100.56} & 1.73 \\
\hline & 6 & 98.51 & & 1.14 \\
\hline & 8 & 100.82 & & 1.15 \\
\hline \multirow{3}{*}{ Benzylamine } & 5 & 101.42 & \multirow{3}{*}{100.07} & 1.27 \\
\hline & 7 & 101.00 & & 0.72 \\
\hline & 9 & 100.79 & & 0.63 \\
\hline \multirow{3}{*}{ Dibenzylamine } & 5 & 99.257 & \multirow{3}{*}{101.32} & 3.01 \\
\hline & 6 & 102.86 & & 2.11 \\
\hline & 7 & 101.85 & & 1.95 \\
\hline \multirow{3}{*}{ Cyclohexylamine } & 4 & 100.84 & \multirow{3}{*}{100.16} & 0.94 \\
\hline & 6 & 98.99 & & 0.86 \\
\hline & 8 & 100.64 & & 0.71 \\
\hline
\end{tabular}




\section{Effect of intereferences}

To check the selectivity of the method, $100 \mu \mathrm{g} \cdot \mathrm{ml}^{-1}$ of ethylamine as a typical aliphatic amine was determined using the recommended procedure in the presence of various foreign organic and inorganic compounds. The results shown in Table (5) indicate that the method was selective. Arginine interferes seriously due to the presence of basic amino group in its side chain.

Table (5): Effect of interferences

\begin{tabular}{|c|c|c|}
\hline Foreign compounds & Fold excess added & Relative error (\%) \\
\hline \multirow{3}{*}{ N-Methyl aniline } & 10 & 0.0 \\
\hline & 15 & 2.2 \\
\hline & 25 & 5.6 \\
\hline \multirow{3}{*}{ Acrylamine } & 10 & 2.0 \\
\hline & 15 & 3.3 \\
\hline & 20 & 6.0 \\
\hline \multirow{3}{*}{$\mathrm{N}, \mathrm{N}$-Dimethyl aniline } & 20 & 0.0 \\
\hline & 25 & 2.8 \\
\hline & 30 & 5.5 \\
\hline \multirow{3}{*}{ Aniline } & 10 & 2.7 \\
\hline & 20 & 5.33 \\
\hline & 40 & 12.6 \\
\hline \multirow{3}{*}{ Benzamide } & 10 & -1.1 \\
\hline & 20 & -4.4 \\
\hline & 30 & -5.5 \\
\hline \multirow{3}{*}{ Acetanilide } & 10 & 2.0 \\
\hline & 15 & 4.0 \\
\hline & 20 & 6.0 \\
\hline \multirow{3}{*}{ EDTA } & 10 & 0.0 \\
\hline & 15 & 3.3 \\
\hline & 20 & 5.3 \\
\hline \multirow{3}{*}{ Glucose } & 10 & 0.0 \\
\hline & 25 & 3.6 \\
\hline & 50 & 5.3 \\
\hline \multirow{3}{*}{ Glycine } & 10 & 1.56 \\
\hline & 20 & 3.9 \\
\hline & 50 & 6.8 \\
\hline \multirow{3}{*}{ Proline } & 10 & 0.0 \\
\hline & 20 & 2.2 \\
\hline & 60 & 6.1 \\
\hline \multirow{3}{*}{ 4-Hydroxy proline } & 10 & 2.6 \\
\hline & 20 & 4.4 \\
\hline & 30 & 8.3 \\
\hline \multirow{3}{*}{ Alanine } & 10 & 2.7 \\
\hline & 20 & 5.3 \\
\hline & 40 & 12.6 \\
\hline
\end{tabular}


Spectrophotometric Determination of Microgram Amounts ...

\begin{tabular}{|c|c|c|}
\hline Foreign compounds & Fold excess added & Relative error $(\%)$ \\
\hline \multirow{3}{*}{ Leucine } & 10 & -1.9 \\
\hline & 20 & -3.7 \\
\hline & 50 & -8.5 \\
\hline \multirow{3}{*}{ Isoleucine } & 14 & -2.1 \\
\hline & 28 & 3.9 \\
\hline & 42 & -9.4 \\
\hline \multirow{3}{*}{ Ammonium chloride } & 10 & 1.1 \\
\hline & 20 & 2.2 \\
\hline & 50 & 6.1 \\
\hline \multirow{3}{*}{ Serine } & 10 & 2.4 \\
\hline & 20 & 3.5 \\
\hline & 50 & 8.0 \\
\hline \multirow{3}{*}{ Tryptophan } & 10 & -1.8 \\
\hline & 20 & -3.5 \\
\hline & 50 & -7.3 \\
\hline \multirow{3}{*}{ Methionine } & 10 & -2.1 \\
\hline & 20 & -4.5 \\
\hline & 50 & -9.0 \\
\hline \multirow{3}{*}{ Threonine } & 10 & 0.0 \\
\hline & 20 & 1.1 \\
\hline & 50 & 6.3 \\
\hline \multirow{3}{*}{ Cysteine } & 10 & 2.6 \\
\hline & 20 & 4.0 \\
\hline & 50 & 9.0 \\
\hline \multirow{3}{*}{ Asparagine } & 10 & 0.8 \\
\hline & 20 & 1.5 \\
\hline & 50 & 6.0 \\
\hline \multirow{3}{*}{ Glutamine } & 10 & 2.1 \\
\hline & 20 & 4.0 \\
\hline & 50 & 9.1 \\
\hline \multirow{2}{*}{ Arginine } & 1 & 92.25 \\
\hline & 2 & 185.48 \\
\hline
\end{tabular}

\section{The nature and stability constant of the coloured product}

The nature of the coloured products was studied by applying Job's and mole ratio methods ${ }^{(23)}$ (Figure 3). 

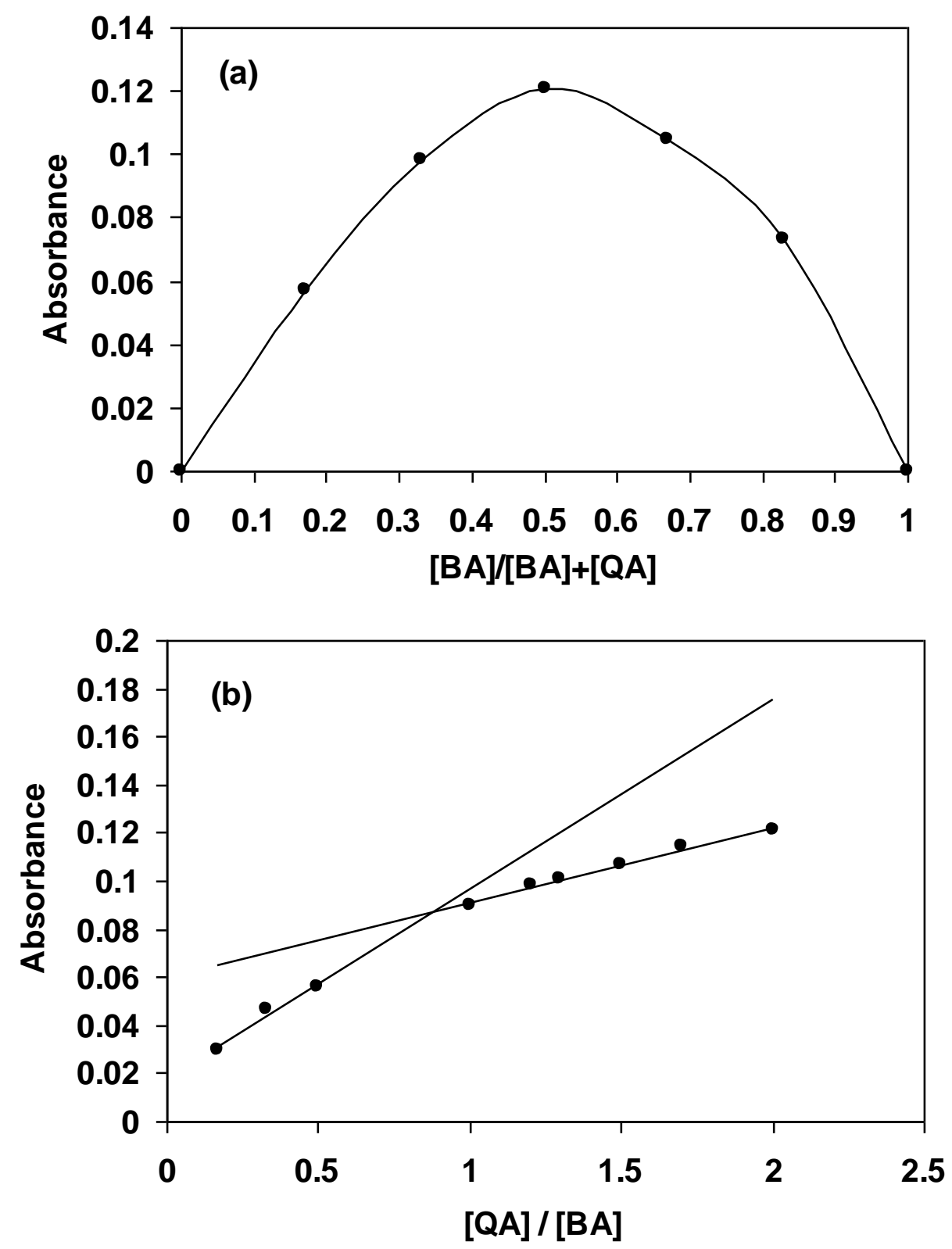

Figure (3): a. Job's method for benzylamine-quinalizarin product

b. Mole ratio method for benzylamine-quinalizarin product

Results show that the mole ratio of quinalizarin to aliphatic amines was 1:1 indicating that one amino group responsible for the formation of the product. Therefore, the formation of the product may occur as follows ${ }^{(24)}$ :

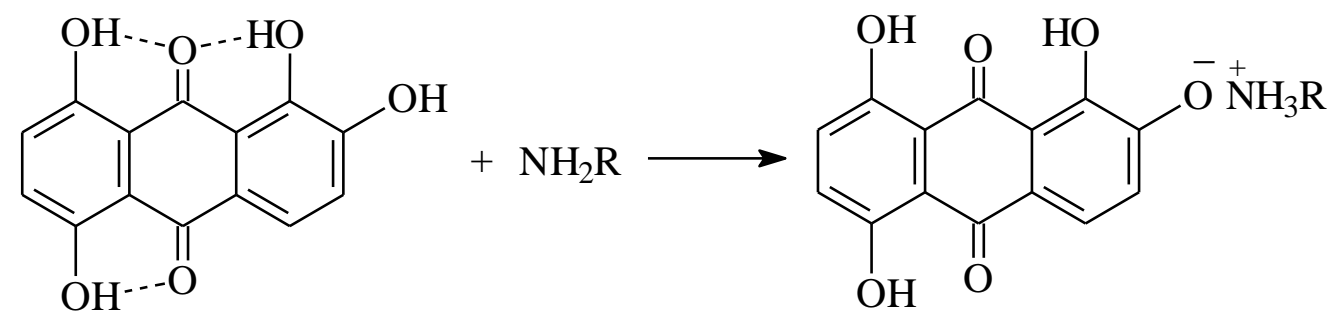


The stability constants of these products were determined (Table 6 ), the results show that the stability constants ranged from $1.00 \times 10^{6}$ $1 . \mathrm{mol}^{-1}$ for ethylamine to $3.75 \times 10^{6} 1 . \mathrm{mol}^{-1}$ for sec-butylamine indicating high stabilities for these products.

Table (6): The stability constants of the products

\begin{tabular}{|c|c|}
\hline Aliphatic amines & $\begin{array}{c}\text { Stability constant* } \\
\left(1 . \mathrm{mol}^{-1}\right)\end{array}$ \\
\hline Ethylamine & $1.00 \times 10^{6}$ \\
\hline sec-Butylamine & $3.75 \times 10^{6}$ \\
\hline tert-Butylamine & $1.55 \times 10^{6}$ \\
\hline Benzylamine & $1.74 \times 10^{6}$ \\
\hline Dibenzylamine & $2.51 \times 10^{6}$ \\
\hline Cyclohexylamine & $2.00 \times 10^{6}$ \\
\hline
\end{tabular}

* Average of three values

\section{Comparison of Methods}

Table (7) gives the results obtained by application of the present method and literature methods to the determination of cyclohexylamine.

Table (7): Comparison of the present method with other methods

\begin{tabular}{|l|c|c|c|}
\hline \multicolumn{1}{|c|}{ Analytical parameter } & $\begin{array}{c}\text { Present } \\
\text { method }\end{array}$ & $\begin{array}{c}\text { Alizarin red } \\
\text { sulphonate (ARS) } \\
\text { method }^{(19)}\end{array}$ & $\begin{array}{c}\text { 2,4-Dinitro-1- } \\
\text { fluorobenzene } \\
\left(\text { DNFB) } \text { method }^{(21)}\right.\end{array}$ \\
\hline$\lambda_{\max }(\mathrm{nm})$ & 560 & 530 & 353 \\
\hline $\mathrm{pH}$ & Without & Without & 8.4 \\
\hline Medium & Aqueous & Aqueous & Organic \\
\hline Temp. $\left({ }^{\circ} \mathrm{C}\right)$ & R.T & 40 & 40 \\
\hline Development time $(\mathrm{min})$ & 10 & 30 & 60 \\
\hline Stability period $(\mathrm{min})$ & 50 & 60 & 30 \\
\hline Molar absorptivity $1 . \mathrm{mol}^{-1} . \mathrm{cm}^{-1}$ & 6690 & 7790 & 13957 \\
\hline Linearity $\left(\mu \mathrm{g} \cdot \mathrm{ml}^{-1}\right)$ & $0.5-10$ & $0.1-10$ & 100.166 \\
\hline Recovery $(\%)$ & 100.16 & 101.03 & $<1$ \\
\hline RSD $(\%)$ & $<1$ & $<1$ & - \\
\hline Analytical application & - & $\begin{array}{c}\text { Pharmaceutical } \\
\text { preparations }\end{array}$ & \\
\hline
\end{tabular}

Results shown in Table (7) confirm that the present method was rapid, simple, has low detection limit, wide range for determination and cheap since it does not require neither organic solvent nor solvent extraction.

\section{CONCLUSION}

A spectrophotometric method has been developed for the determination of aliphatic amines in aqueous solution, based on proton transfer reaction with quinalizarin reagent. The method was simple, sensitive, low cost and does not require solvent extraction. 


\section{REFERENCES}

1. Schmid G.H., "Organic Chemistry", Mosby-Year Book Inc., New York, p. 971, (1996).

2. McMurry I., "International Student Edition Organic Chemistry", $6^{\text {th }}$ edn., Brooks/Cole Thomson, Inc., p. 892, (2004).

3. "Encyclopedia of Chemical Technology", $1,3^{\text {rd }}$ edn., John Wiley and Sons, Inc., New York, pp. 279-280, (1978).

4. Lichtenberger L. M., Graziani L. A. and Dubinsky W. P., Am. K. Physiol. Gastrointest Liver Physiol., 243, 5, 341-347, (1982).

5. Shenk G. H., Vanle D. W., Pietrandred J. and Mojzis C., Anal. Chem., 372, 37, (1965).

6. Benson G. A. and William W. J., Anal. Chem., 214, 48, (1976).

7. Wachsmuth H. and Koeckhoven L. V., J. Phar. Belg., 220, 17, (1962); Chem. Abs., 6400c, 61, (1964).

8. Sharma J. P. and Tiwari R. D., Michrochem. J., 17, 51, (1972).

9. Tshima Y., Hasegawa H. and Yukiura H., Jpn. Analyst, 43, 19, (1970).

10. Yuki H., Matsuda S., Tokuda Y. and Takiura K., Mikrochim. Acta, [Wien], 132, (1972).

11. Al-Ghabsha T. S., Rahim S. A. and Townshend A., Anal. Chim. Acta., 189, 85, (1976).

12. Al-Sabha T.N., M. Sc. Thesis, University of Mosul, (1984).

13. Al-Ghabsha T. S., Rahim S.A. and Hanna G. K., J. Edu. and Sci., 23, 42, (1995).

14. Al-Ghabsha T. S., Rahim S. A. and Al-Sabha T. N., J. Edu. and Sci., 46, 37-50, (2000).

15. Al-Ghabsha T. S., Al-Sabha T. N. and Omar K. M., J. Edu. and Sci., 51, 73-81, (2001).

16. Al-Mtaiwti S. M. J., Ph.D. Thesis, University of Mosul, (2004).

17. Al-Abachi R. Y., M.Sc. Thesis, University of Mosul, (2000).

18. Awad F. H., Ph.D. Thesis, University of Mosul, (2000).

19. Al-Delymi A. M. S., Ph.D. Thesis, University of Mosul, (2006).

20. Al-Obaidi M. T. H., M.Sc. Thesis, University of Mosul, (2001).

21. Al-Hamody E. A. S., M.Sc. Thesis, University of Mosul, (2005).

22. Al-Neaimy U. I. S., Ph.D. Thesis, University of Mosul, (2006).

23. Delevie R., "Principle of Quantitative Chemical Analysis", McGraw-Hill, New York, p. 498, (1997).

24. Khranina O. V., Chernuakovskii F. P. and Denisov G. S., J. Mol. Struct., (1987), 177, 309-315; Chem. Abst., (1989), 111, 38746w. 